\title{
Kozmetik Zincir Mağazalarda Etnografik Kullanıcı Deneyimleri: Heyecan Veren, Aranan Bulunulan, Öylesine Uğranılan (Ethnographic User Experiences At Cosmetic Chain Shops: Exciting, I Find What I Am Looking For, And Just Stopped By)
}

\section{Mustafa Şeref AKIN iD a}

a Erzincan Binali Yıldırım Üniversitesi, İktisadi ve İdari Bilimler Fakültesi, Erzincan, Türkiye. mustafa.akin@erzincan.edu.tr

\begin{tabular}{ll}
\hline MAKALE BÍLGIsI & ÖZET \\
\hline Anahtar Kelimeler: & Amaç - Bu makalede etnografik mülakat metodu kullanılarak kozmetik sektöründe zincir \\
Kullanıcı deneyimi & mağazalarda tüketicilerin duygusal, sosyal, bilişsel kullanıcı deneyimleri gösterilmektedir. \\
Etnografi & Kullanıcıları yaşadıkları derinden hikayeleri, beklentileri, sevinçleri, hayal kırıklıkları \\
Kozmetik zinciri & incelenmektedir. Kozmetik zincirindeki mağazanı ürününden, reyon düzenine, insan \\
& kaynaklarından, renklerine kadar tasarım-müşteri ilişkileri-deneyimsel model bazlı değişikliklere \\
& gitmesi önerilmektedir.
\end{tabular}

Gönderilme Tarihi 12 Ağustos 2020

Revizyon Tarihi 8 Şubat 2021

Kabul Tarihi 2 Mart 2021

Makale Kategorisi:

Araştırma Makalesi
Yöntem - Etnografik mülakat kullanıcının deneyimleri üzerinden yapılan araştırmadır. Özellikle duygusal ve bilişsel deneyimlerinin anlaşılmasına gayret gösterilmektedir. Bu süreç Türkiye'de zincir kozmetik mağazası olan ve kitlesel satış yapan markalar üzerinden örneklenmiştir. Etnografik mülakata katılanlar yoğunlukla tercih edilen bu üç grup markayla daha önce alışveriş gerçekleştirmişlerdir.

Bulgular - Zincir mağazalar arasında kullanıcı deneyimi açısından elde edilen iç görülere göre üç kategori belirlendi: Heyecan veren, aranan bulunulan ve öylesine uğranılan. Heyecan veren zincir mağazasında kadınların yıl dönümleri gibi özel günlerde veya aralıklı sürprizlerle hatırlanıp bol indirim imkânı sağlanmaktadır. Ürün kalitesi algısı ve kullanıcıya özeni mükemmeldir. Aranan bulunanda kozmetik ihtiyacın beklendiği kalite ve hizmet iyi bir standartla sağlamaktadır. Öylesine uğranılanda ise kullanıcılar mağazaya bir de buraya bakayım düşüncesiyle girmektelerdir. Ürün ve servis kalite algısı düşüktür. Almak için özendirici bir ortam yoktur.

Tartışma - Kozmetik sektöründe kadın açısından tercih edilmede önemsenmek, özen gösterilmek, rahat hissetmek markayla iletişimde öncelikli duygulardır.

\section{ARTICLE INFO}

Keywords:

User experience,

Ethnography

Cosmetic chain

Received 12 August 2020

Revised 8 February 2021

Accepted 2 March 2021

Article Classification:

Research Article

\section{ABSTRACT}

Purpose - This article demonstrates the importance of emotional, social, and cognitive user experience in the ethnographic interview and cosmetic industry. Understanding the stories, expectations and disappointments of the users deeply will enable cosmetic shops changes from the product of the store to the aisle layout, from human resources to colors in design-customer relationsexperiential environment.

Design/methodology/approach - The ethnographic interview is research done through user's experiences. Particular efforts are made to capture emotional and cognitive experiences. A case on this process has been demonstrated through cosmetic chain brand stores in Turkey. Participants in the ethnographic interview have previously shopped with all three groups of brands.

Findings - Among the chain shops, there are three categories in terms of user experience: exciting, where I find what I am looking for, and just stopped by. In the exciting experience, the chain shop offers plenty of discounts for women on special days such as anniversaries or with occasional surprises. The perception of product quality and care for the user is magnificent. When I find what I am looking for, it provides the quality and service that I expect for my daily cosmetic needs with a good standard. In just stopped by, the user enters the shop with the thought of checking here. The perception of product and service quality is low. There is no encouraging environment to take.

Discussion - From the women' point of view, being cared and feeling comfortable in the cosmetics industry are important emotions in communication with the brand. 


\section{Giriş}

Markanın tüketicisiyle sağlıklı ilişkisi dinleme ve deneyim yaşatmasıyla olmaktadır. Tüketicinin dinlenmesi etnografik yöntemleri kullanarak gerçekleştirildiğinde arzulanan duygusal, sosyal ve bilişsel deneyimler ortaya çıarılmaktadır. Sonrasında markanın bu beklentileri gerçekleştirmesi hem organizasyonunu (üretim, insan kaynakları, tasarım, mağaza dizaynı, ar\&ge) hem de markayı (iletişim, lokasyon) konumlandırmasıyla gerçekleşir. Bu makalede kullanıcı deneyiminin en yoğun yaşananlardan biri olan kozmetik sektöründe zincir mağazalar üzerine etnografik mülakatlar gerçekleştirilmiştir. Mülakatlar sonucu tüketicilerin duygusal, sosyal ve bilişsel deneyimleri ortaya çıkarılmıştır.

Amerika Birleşik Devletleri tüketim ürünlerin kategorisinde şirketler her yıl 30.000 yeni ürün piyasaya sürmekte, ancak \%70 ila \%90'ı bir yıldan az bir sürede piyasadan çekilmektedir (Gourville, 2006). Nielsen'ın 2012-2016 Çığır Açan İnovasyon" raporunda değerlendirilen 20.000 yeni tüketici ürününün sadece 92'si (\% 1'den az) ilk iki yılda 50 milyon dolardan fazla satışa ulaşabilmektedir (Hall ve Wengel, 2016). Bain \& Company'nin 362 şirketin müşterileri ile yaptığı anket çalışmasında müşterilerin sadece \% 8'i deneyimlerini "üstün" olarak nitelendirirken, ankete katılan şirketlerin \% 80'i sağladıkları deneyimi üstün olduğuna inanmaktalar (Blasberg vd., 2007). Başarısızlığın temel sebebi kullanıcının beklentilerinin karşılanmamasıdır.

Kullanıcıların alışveriş kararlarının \%95'i duygusaldır (Zaltman, 2003; Zaltman ve Zaltman, 2008). Üreticiler için, kullanıcıların davranışlarının, motivasyonlarının, düşüncelerinin, duygularının, ortamlarının ve beklentilerinin anlaşılması bir ürünün başarısını belirlemektedir (Akın, 2019a). Kullanıcı deneyimi çalışması marka hikayesi ortaya çıkarmak, daha yenilikçi olmak, pazarlama stratejilerini geliştirmek amaçlarını taşımaktadır (Zaltman ve MacCaba, 2007).

Kozmetik sektöründe marka, ürün, reklam, kadın temalı birçok çalışma gerçekleştirilmişken zincir mağazalar üzerine yapılan çalışmalar nadirdir (Devrani, 2009: 407, Nardalı ve Balkan, 2019). Halbuki zincir mağazalar sadece bir dağıtım kanalı değil aynı zamanda bir pazar yeridir. Ayrıca kadınların ürünler hakkında danışmanlık aldıkları, satış elemanları ve güzellik uzmanları tarafından marka ve ürün üzerine onanma sağlanan mekanlardır. Üstelik, bu kozmetik zincirleri kendi markalarını da üretmektelerdir. Duygusal yönü erkeklere göre daha ağır olan kadınların en hassas oldukları güzellik ürünlerinde duygusal ve sosyal beklentilerinin çözülmesi kullanıcı deneyimi araştırmalarına farklı bir boyut katmaktadır. Müşterilerin yüzde 40 ile 50'si bir kozmetik mağazasına girdiklerinde etkilenebilir veya ikna edilebilir; bu da pazarlamacıların ikna edici satıcılar, çekici ambalaj, ücretsiz örnekler gibi doğru promosyon araçlarını kullanarak karar verme sürecini kesintiye uğratma şansına sahip olduğu anlamına gelmektedir (Court ve diğerleri, 2009; Yang ve Lee, 2016). Bundan dolayı, bu çalışmanın amacı etnografik mülakat metodu kullanılarak kozmetik zincir mağazalarda kadın müşterilerin tüketim tercihlerinin ardındaki duygusal, sosyal, bilişsel deneyimlerini bularak, doğru pazarlama, organizasyon, ürün, markalaşma stratejilerini oluşturmaktır.

Etnografik araştırmalarda kullanıcılara müşteri kategorileri olarak yaklaşılmamaktadır. Sosyo-ekonomik ve demografik varsayımlar oluşturulmamaktadır. İnsanlar için neyin anlamlı olduğunu ve bireylerin günlük hayatı nasıl deneyimledikleri öğrenilmektedir. Nedensellik insanların bu ürünü neden kullandığını işaret etmektedir. Kullanıcıyı harekete geçirmede en temel neden duygusal faktördür (Zaltman, 2003: 25-30; Yang ve Lee, 2016: 37). Etnografi bu duyguları ortaya çıkarmayı hedeflemektedir. Özellikle zincir mağazanın markalar arasında tüketici alım değişikliği yapmasında \%50 etkiye sahip olduğu düşünülürse, kullanıcı deneyimlerinin önemi daha iyi anlaşılır (Yang ve Lee, 2016: 37). Diğer niteliksel ve niceliksel yöntemler olan anketler, odak grupları ve araştırma raporları ile kullanıcının öngörülemeyen davranışları anlaşılamamaktadır (Young, 2015: 18-22). Etnografik metotlar kullanıcıların düşüncelerini, duygularını, karmaşık sorunlarının anlaşılmasına ve inovatif şekilde çözülmesine yardımcı olmaktadır (Creswell ve Creswell, 2017: 45-65). Empati kurmak için kullanıcılar derinlemesine dinlenmelidir (Kumar, 2012; Zaltman ve Zaltman, 2006: 40-42).

Tüketiciler satın alma kararlarını fonksiyonel ihtiyaçların karşılanmasından ziyade ürünlerin sağladıkları duygular ve deneyimlere göre vermekteler (Walls vd., 2011; Kabadayı ve Alan, 2014). Kozmetik sektöründe tüketici kadınlar zincir mağazada hangi duyguları ve deneyimleri yaşamak istemektelerdir?

Rakiplerine göre eşsiz ve unutulmaz deneyimlerle farklılaşma, tüketicileri markaya sadık hale getirmenin en temel yollarından biridir (Kabadayı ve Alan, 2004). Bir anlamda, tüketiciler ürünlerin fonksiyonları yerine 
sağladıkları duygusal tatminleri tüketmektedirler (Aykaç ve Kervenoael, 2008). Tüketici davranışları ve kullanıcı deneyimi araştırmalarında önemli olan tüketici için hangi üründe hangi deneyimin ön planda olduğunu ortaya çıkarmaktır. Kullanıcının araba galerisinde ve kozmetik mağazasında farklı deneyim yaşamaya ihtiyacı vardır.

\section{Müş̧teri Deneyimi}

Müşteri deneyimi bir firma ile müşteri arasındaki ilişki süresi boyunca gerçekleşen etkileşimin sonucudur. Bu etkileşim üç bölüme ayrılabilir: Müşterinin ihtiyacının ortaya çıkması (tetikleyen unsurlar), müşteri ile yüz yüze etkileşim kurduğu marka temas noktaları ve müşterinin tüketimi sırasında deneyimledikleridir (dijital ortam dahil). Tatminkâr müşteri deneyimi, bireyin tüm temas noktalarındaki deneyiminin bireyin beklentileriyle eşleştiği anlamına gelmektedir (Thompson ve Kolsky, 2004). Fiziksel, psikolojik, sosyal ve kültürel deneyimler yoluyla olan bu ihtiyaçların giderilmesi gerekmektedir (Verhoef vd., 2009; Kabadayı ve Alan, 2014: 204). Müşteriler, bir markayla doğrudan ve dolaylı iletişim içindedirler (Janakiraman vd., 2006). Doğrudan temas genellikle satın alma veya kullanımı müşteri tarafından başlatıldığında gerçekleşmektedir. Dolaylı temas reklamları, haberleri, satış temsilcileriyle karşılaşmaları, ağızdan ağza tavsiyeleri veya eleştirileri içermektedir (Meyer ve Schwager, 2007).

Tüketim karar süreci, kişilerin ihtiyaçları dışında çevresindekilerin beklentilerini karşılayabileceğini düşündükleri ürün ve hizmetleri belirlemeyi de kapsamaktadır. Tüketim kararının uygulanmasında zaman, para ve çaba harcanmaktadır. Ayrıca satın alındıktan sonra kullanma, geri iade, elden çıkarma gibi davranışlar da incelenmektedir (İslamoğlu ve Altunış1k, 2008: 136; İnceoğlu 2010: 28; İmam, 2013: 23).

Müşteri deneyimi, bir şirketin değer teklifinin her yönünü kapsamaktadır: Müşteri hizmetleri kalitesi, reklam, ambalaj, ürün ve hizmet özellikleri, kullanım kolaylığı ve güvenilirlik (Meyer ve Schwager, 2007). Operasyon birimi açısından önemli olan kalite, zaman ve maliyettir. Müşteri hizmetleri açısından işlem sürecine odaklanılmaktadır. Ancak işlemden öncesi veya sonrası ile bir bağlantı kurmamaktadır. Gerçekten neden müşteri bu ürüne talep etmiştir sorusuna cevap aranmamaktadır (Meyer ve Schwager, 2007).

Forrester Research'e göre, mükemmel müşteri deneyimi için altı disiplinin birleşmesi gerekmektedir: Strateji, müşteriyi anlama, tasarım, ölçüm, yönetişim ve kültürdür (Manning and Bodine, 2012). Bir şirketin, kendisini müşterilerinin gözünde farklı kılan bir deneyim sunma yeteneği, tüketici harcamalarını ve markaya sadakati arttıracaktır. Sadakat bir şirketin müşterileriyle etkileşimi ve onların istek ve ihtiyaçlarını ne kadar iyi karşıladığından kaynaklanmaktadır (Sebor, 2008).

Müşteri odaklılık olgunluğu açısından dört aşama mevcuttur:

Ürün odaklılık: Firmalar mal üretir ve tüketicilere çok iyi şekilde sunarlar.

Pazar odaklılık: Tüketici talepleri ve segmentasyon üzerinden ürün kategorileri geliştirirler.

Müşteri deneyimi: Kullanıcıların motivasyonlarına uygun şekilde duygusal deneyim yaşatmaktalar.

Özgünlük: Ürünler ve hizmetler, markanın gerçek ruhundan doğmaktadır. Müşteriler ve diğer paydaşlar ile doğal ve uzun vadeli sürdürülebilir bir temelde bağlantı kurmaktadır (Khan, 2013).

Tüketici kararları; bireylerin ve grupların, ihtiyaçların giderilmesinde hangi duygulardan etkilendiklerini, hangi kaynaklardan nasıl kullandıklarını ve satın alımlarını nasıl gerçekleştirdiklerini kapsayan bir süreçtir (Lembet, 2010: 305; Babaoğul ve Bener, 2010: 103).

Karar süreci belirlenen hedefin başarılmasında içinde motivasyon barındıran bir süreçtir. Tüketici davranışlarının odağında bu motivasyon araştııılmaktadır (Coşgun, 2012: 838). Kotler ve Armstrong'a göre (2010:177) tüketici satın alma kararı 5 aşamada gerçekleşmektedir: İhtiyacın belirlenmesi, bilginin toplanması, alternatiflerin değerlendirilmesi, satın alma, satış sonrası değerlendirme. Karar alma da kişisel, sosyal, ekonomik, psikolojk faktörler önemlidir (İslamoğlu ve Altunışık, 2008: 136; İnceoğlu 2010: 28; İmam, 2013: 23; Marangoz, 2007: 107; Kahle ve Kim, 2006: 55-60):

Tüketici karar süreçlerinin araştırılmasında davranışsalcılığın, psikolojinin, sosyolojinin ve antropolojinin katkısı büyüktür. Özellikle etnografik araştırmalar bu disiplinlerden gelen metodoloji sayesinde tüketici davranışlarına ışık tutmaktadır. Tüketici davranışlarının en yoğun etkilenen tüketicide yaşatılan psikolojik 


\section{M. Ş. Akın 13/1 (2021) 13-28}

deneyimlerdir (Varinli, 2006). Bundan dolayı psikolojik faktörler olan ihtiyaç ve güdüler, algılama, öğrenme, inanç ve tutumlar, kişilik, yaşam biçiminin anlaşılmasında etnografiden faydalanılmaktadır.

Deneyimler duygusal değerler içererek ürünün sunduğu fonksiyonel ihtiyaçların yerine geçmektedir. Bu pazarlama yönteminde ürünleri fonksiyonlarını öne çıkarmak yerine; ürünlere "deneyiminin" bir parçası olarak yaklaşılmaktadır. Tüketim sadece ürünü kullanmak değil tüm deneyimleri içerecek şekilde bütünseldir. Klasik pazarlama hedefi olan marka ya da ürün temelli rekabetten ayrılmaktadır (Schmitt, 1999; Kumar, 2012).

Duygusal deneyimde kullanıcıların hangi duyguları tecrübe ettikleri anlaşılmaktadır. Tüketicilerde markayla ilgili güçlü ve olumlu duyguların yaşatılması sağlanmaktadır (Kumar, 2012; Yu ve Ko, 2012). Farklı deneyim türleri vardır. Sosyal deneyimden kişilerin çevreleriyle sosyalleşme süreci incelenmektedir. Bilişsel deneyimde iletişimde oldukları nesnelere yükledikleri anlamlar analiz edilmektedir. Müşterilerde problem çözücü deneyimler kurgulanması amaçlanmaktadır (Schmitt ve Zarantonello, 2013). Kültürel deneyimde yaşadıkları toplumda kişilerin edindikleri normlar öğrenilmektedir. Fiziksel deneyimde kişilerin nesnelerle fiziksel iletişimi tanımlanmaktadır.

\section{Kozmetik Sektörü}

Kozmetik sektörü üzerine yapılan çalışmalarda yenilik, kadın, güzellik, marka sadakati, ticari amaçlar, trendler ve erkeklerin tutumu üzerinde durulmuştur (Oğuz, 2013: 184; Devrani, 2009: 407). Kozmetik mağazalarının satış kanalı olarak tüketici kararını ciddi şekilde etkileyebilecek mekanlardır (Yang ve Lee, 2016). Özellikle duyguların tüketim davranışında etkisi anlaşıldıkça zincir mağazalarda müşteri deneyimi kavramı gelişmektedir.

Yenilikte, kozmetik endüstrisi, çok karlı ve hızlı tempolu bir endüstridir. Ürün yeniliği, başarının anahtarıdır (Kumar vd., 2006). Bu kozmetik şirketlerinin her biri satış yöntemi, pazarlama stratejisi, ürün grubu ve dağıtım kanalı açısından benzersizdir. Kozmetik pazar yerleri kozmetik sektöründe şirketlerinin konumlandırma stratejilerinin bir parçasıdır. Ayrıca kozmetik mağazaları zincir mağazalar içinde yüksek ciro ve kar sebebiyle büyük yer almaktadır (Lee, 2010). Bu nedenle kozmetik mağazaların idaresi önemlidir.

Kadınlık konusunda, kozmetik firmalarının seçtiği ideal güzellik kavramının ataerkil yaklaşımların reklamlar vasıtasıyla tekrar canlandırıldığı gösterilmiştir (Oğuz, 2013: 184).

Çalışan kadınların kozmetik ürünlerine yönelik marka sadakati üzerine analiz yapılmıştır. Marka ününün, marka deneyiminin, marka tatmininin ve arkadaş grubu onayının sadakati belirleyen faktörler olduğu görülmüştür (Devrani, 2009: 407)

Kozmetik sektörünün seçtiği reklam formatlarının geleneksel toplumunun dişına çıkan sosyo-ekonomik statüsü güçlenen kadının imajına uygun olarak değiştirildiği gösterilmiştir. Kadının işteki, evlilikteki, ailedeki düşünceleri ve kaygıları reklamlarda yansıtıldığı belirlenmiştir (Özden ve Özden, 2020: 1).

Kozmetik sektöründe ticari olarak gelişme özellikle zenginleşmekte olan gelişmekte olan ülkelere kaymaktadır. Burada özellikle Çin, Brezilya ve Rusya önemli rol oynamaktalar (Lopaciuk ve Loboda, 2013).

Sosyal medyanın etkinleşmesi pazarlama faaliyetlerinin önemli parçası haline gelen kozmetik sektörünün de ilgisini çekmiştir. Kozmetikte tüketicilerin yüzde 60'ı alışverişten önce internette arama yapmaktadır (Court vd., 2009). Sosyal medya fenomenlerinin tanıtımını yaptıkları ve kendi adlarını taşıyan ürünlerin tüketime ve tanıtıma katkısı üzerine araştırmalar yapılmıştır (Nardalı ve Balkan, 2019). Sosyal medyada fenomenlerinin tüketime etkisinin kısıtlı olduğu ama tanıtıma büyük katkı sağladığı tespit edilmiştir. Tüketimi frenleyen bir unsurunun denemeden alınmasında kadınların yaşadığı tereddüttür.

Erkeklerin kozmetik ürünlerine bakışı konusunda çalışmalarda kadınlar kadar düşkün olmasalar da büyüyen pazar olarak karşımıza çıkmaktadır. Özellikle imaj, fiziksel çekicilik, yaşlanma, sağlık durumu, hayat tarzı faktörleri ve reklam tüketimi artırmaktadır (Souiden ve Diagne, 2009).

Kozmetik mağazalar hala müşterilerin kozmetik ürünlerini satın alabileceği önemli bir kanaldır (Yang ve Lee, 2016). Kozmetik sektörünün öncü ülkesi Fransa'da kozmetik perakende sektörü iki nedenden dolayı değişim göstermektedir. Birincisi, kozmetik mağazalarında giderek daha fazla hizmet sunmakta ve ikincisi, LVMH 
veya Marionnaud gibi büyük gruplar dağıtımları üzerinde daha fazla kontrol sağlamak için perakende zincirlerini satın almaktalar (Cliquet ve Croizean, 2002: 238).

Kozmetik mağazasına giren müşteriler müşteriler dörde ayrılmaktadırlar (Clark, 2008): 1. Bir markayı satın alma niyetiyle girip daha fazlasını satın alanlar. 2. Bir markayı satın alma niyetinde olup ancak başka bir marka satın alanlar 3. Satın alma niyeti olmadan girip tercih edilen marka ürünleri satın alanlar 4. Satın alma niyeti olmadan girip mağaza içindeki promosyonlarla ürünleri satın alanlar. Sonuçta kozmetik mağazası daha fazla veya daha farklı markanın alınmasına etki yapabilmektedir.

Kozmetik mağazalarında ürün kadar hassas nokta tüketiciyle satış temsilcileri arasındaki temastır. Deneysel pazarlama keyifli bir deneyim yaratma ve tüketici için eğlenceli hale getirmeye çalışmaktadır (Srinivasan ve Srivastave, 2010). Hatta deneyimsel pazarlamada satış elemanı ve tüketiciler arasındaki ilişki maldan önceliklidir (Meyer, 2006). Dolayısıyla kozmetik tüketicilerin motivasyonunu ve mağazada geçirdikleri süreyi arttırmak olumlu deneyim yaşatmaktan geçmektedir (Srinivasan ve Srivastave, 2010).

\section{Yöntem: Etnografik Mülakat Yapısı ve Protokol}

\subsection{Etnografik Temeller}

Mülakat, sorular sorarak kullanıcıya yaklaşmanın bir yoludur (Nielsen, 2000). Etnografik mülakat, yapısı ve amacı olan bir konuşmadır. Kullanıcıların iç seslerinin, niyetlerinin ve amaçlarının ne olduğu sorulmaktadır. Amacı kullanıcılardan hikayeler elde etmektir. Hayatlarını, deneyimlerini ve bakış açılarını anlatmaları istenmektedir.

Etnografik mülakatta genelden özele inilmektedir (Elliot ve Elliot, 2003: 222; Beckman ve Barry, 2007: 49). Önce kullanıcının çevresi ve hayat bakış açısı anlaşılmaktadır.

Somut hikayeler aranmaktadır (Liedtka ve Ogilvie, 2011: 67-70; Akin, 2019a: 25). Soyut yorum sorusu sorulmamaktadır.

Takip soruları derine inmeyi sağlamaktadır. Yüzeysel bilgiler güvenilir değildir. Daha derinlere inildikçe kullanıcının akıl yürütmesini, tepkilerini, yol gösterici ilkelerini, motivasyonlarını ne olduğu öğrenilmektedir. Bunlar güvenilir ve açık yanıtlardır (Merriam ve Tisdell 2015; Luma Institute, 2012).

Kullanıcılara görüşmeler sırasında çözüm sunulmamaktadır. Sadece problemleri ortaya çıkartılması amaçlanmaktadır (Young, 2015).

Mülakata ısınma turuyla başlanmaktadır. Mülakatlarda hem kullanıcıların hem de araştırmacıların zorlandıkları durumlar olabilmektedir (Akın, 2020).

Duygusal ve sosyal deneyimleri kavramak fiziksel deneyimleri kavramaktan daha önemlidir (Liedtka vd., 2014). Ürünler, etkinlikler ve ortamlarla ilgili duygusal deneyimler anlaşılmaya çalışılmaktadır (Moisander ve Voltanen, 2011; Canniford,2005: 217).

Empatik bir dinleyici bulduklarında kullanıcılar açılmaktadır (Stanford Design School, 2009). Yönlendirilme sorusu yönlendirilmemektedir.

Uzun cevapları içeren sorular sorulmaktadır (Coulter vd., 2001: 57). Kısa cevap derinlemesine inilmesini engellemektedir. Özellikle kullanıcıların başlarından geçen hikayeler uzun cevap içermelidir.

\subsection{Mülakat Protokolü Kuralları}

Mülakat 10 kuralı takip etmelidir. Sorulması gereken soru şekilleri şunlardır: (i) ucu açık soru, (ii) takip sorusu (niçin), (iii) somutluk, (iv) duygusal \& bilişsel deneyimler. Sorulmaması gereken soru tarzları ise: (v) kısa, (vi) evet/hayırlı (vii) genel \& yorum bazlı, (viii) fonksiyonel. Mülakat esnasında (ix) empatik dinleyici olarak , (x) yönlendirici \& manipülatif soru sorulmaz (tablo 1) (Kumar, 2012; Luma, 2012; 2014).

Kısa cevaplı soruların aksine açık uçlu sorular sorulmaktadır. Nitel araştırmanın temel bileşeni katılımcının deneyimlerinin derinlemesine incelenmesidir. Mülakat olanların düşünceleri sansürlenmeden akıllarındakini konuşmaları teşvik edilmektedir. Katılımcılara yanlış veya doğru cevap olmadığı bildirilmektedir. Özgürce konuşmalarına ve ayrıntılara girmelerine teşvik edilirler. Röportajı bitirmeden önce ilginç bir açı uçlu soru şu olabilir: "Size sormayı atladığım bir soru oldu mu?" 
Evet / hayır içeren cevaplardan kaçınılır. Uzun cevaplı sorular sorulur. Hikâye tabanlı sorular beklenildiği gibi uzun cevaplar içermektedirler. Mülakatı yapanlar her zaman katılımcıları konuşturmaya çalışmazlar. Görüşülen kişilere boşluğu doldurmak için fırsatlar vermek için sessizlik anlarının olmasını tercih edilir. Üç tip duraksama vardır: Sessiz kalınan ve cevap verenin devam etmesini beklenen sessiz bir duraksama (silent probe); yanıtlayanın söylediği son şeyi tekrarlanan ve devam etmelerini istenen yankı duraksaması (echo probe); söylenenler doğrulayan olumluluk duraksaması (affirmative probe) (Merriam ve Tisdell, 2017).

Somut sorular sorulmaktadır. Soyutlanmış, kanaat temelli ve genelleştirilmiş bilgilerin aksine belirli ve kesin bilgilere ulaşılmak istenmektedir.

Deneyimlere odaklanılmaktadır. Duygusal, bilişsel, sosyal ve kültürel deneyimler birincil öneme sahiptir. İnsanlar fonksiyonel hesaplamalardan ziyade duygulara dayanarak karar verirler. Kullanıciların deneyimlerinden yararlanılmaktadır. Görüşme yaparken alışılmadık ve şaşırtıcı noktalara dikkat edilmektedir (Lietdka ve Ogilvie, 2011).

Yönlendirme ve yargılama soruları sorulmaz. Empatik bir dinleyici olunur. Cevap verebileceği farklı yolların iyi veya kötü olup olmadığı hakkında herhangi bir görüş belirtilmez.

\subsection{Mülakat Protokolü ve Örnekleme}

Araştırmanın evreni Türkiye'nin her yerinde yaygın olarak bulunan orta segment kozmetik markalarını kullananlardan oluşmuştur. Üst segment lüks marka ve çarşı işi markasız kullananlar araştırmanın dışında tutulmuştur.

Örneklemi oluştururken muhakkak bu orta segment kozmetik zincir markalardan alış-veriş yapan ve hikayesi olanlar üzerinden gerçekleştirilmiştir. Mülakatta soru sorulacak kişinin anlamlı kılan hikayesinin uzunluğu, detayları ve derinine doğru deneyimine gidilmesidir. Sosyo-ekonomik ve demografik özellikleri gözetilmemiştir. Motivasyonlarına odaklanılmıştır. Karar alma süreçleri anlaşılmaya çalışılmıştır. Sadece kozmetik sektöründe hikayesi olan ve bu konuda hassasiyetleri olan kişiler daha çok kadınlar olması sebebiyle mülakat ağırlıklı olarak kadınlarla yapılmıştır.

Örnekleme sayısı mülakatlarda alınan cevap benzerlik (kalıp, örgü) oluştuktan sonra bırakılmıştır. Örgü oluşması, 20 hikayesi olan kadın ağırlıklı kullanıcılarla uzun mülakat sonrasında gerçekleşmiştir (Nielsen, 2020: 1; Faulkner, 2003). Etnografik araştırmalar istatistik üretmemektedir. Anket yapılması gereken n sayıda katılımcı yoktur. Katılımcılarla yoğun mülakat yapılır. Kullanıcıların hikayelerinden kalıplar ortaya çıkıncı kadar mülakat serisine devam edilir. Anket çalışmaları korelasyon vermekte ve yüzeysel kalmaktadır (Christensen, 2016). Etnografik derinlemesine mülakatta kişinin davranışlarının ardındaki sebep-sonuç ilişkileri yakalanmaktadır. Ardındaki sosyal, duygusal, bilişsel ve kültürel sebepler ortaya konmaktadır. 10 kullanıcının sorunların \%75 ve üstünü yüzeye çıkardıkları görülmektedir (Nielsen, 2000:1; 2020:1; Faulkner, 2003: 382). Burada esas olan, kullanıcıların deneyimlerinden bir trend çıkıncaya karşı derinlemesine mülakatlara devam etmektir. Kullanıcı ifadeleri italik şeklinde ve kullanıcı numarasıyla (K) yazılmaktadır.

Sorular oluşturulurken tablo 1.'deki prensipler çerçevesinde belirlenmiştir. Mülakat kuralları: açık, belli, yönlendirici olmayan, duygulara, ilişkilere, düşüncelere odaklı ve iyi dinleyici olmaktır. Cevaplar tekrarladığg noktada bırakılmıştır. Soru gidişatı kullanıcıdan gelen cevaplara göre esnetilmiştir (semi-structure).

Somut hikayesini anlatmasını kolaylaştırmak için, mülakat olan kişilere orta segmentdeki $X, Y, Z$ vb. zincir kozmetik markalar üzerinden sorular hazırlanırken, aynı segmentdeki diğer markaları deneyimlerine göre karşılaştırmaları istenmektedir. Böylece, $X^{\prime}$ deki veya Y'deki yaşadığı somut deneyim daha belirgin şekilde kullanıcının hafızasından dökülmüştür. Marka isimleri sadece hafızasındaki anısını anlatmasını kolaylaştırmak için kullanılmıştır. Temel amaç duygu deneyimlerini toplamaktır.

Mülakata katılanların tamamı zincir kozmetik mağazalarını kullanmışlardır. İtalik olarak yazılanlar paydaşların yorumlarıdır. Mülakatta kozmetik zincirleri arasında kullanıcı deneyimi açısından orta, iyi ve olağanüstü olarak 3 kategori ortaya çıkmıştır. Orta kalitede kullanıcı deneyimi sunan marka A, iyi kalitede sunana B ve olağanüstü deneyim sunana $C$ olarak adlandırmıştır.

Yarı yapılandırılmış mülakat tercih edilmiştir. Tablo 1.'deki mülakat soruları hazırlanmış ve kullanıcının cevaplarına göre ilerlenmiştir. Mülakatlar 2019 yılında gerçekleştirilmiştir. Örneğin kullanıcılara markaların kullandıkları malzemeler üzerinden soru hazırlanmazken, kullanıcı bu konuyu açtı̆̆ında (sürpriz şekilde), 


\section{M. Ş. Akın 13/1 (2021) 13-28}

bunun üzerinden sorular sormuştur. Burada yakalanılması gereken anahtar öğe malzemenin performansı değil kullanıcıda oluşturduğu bilişsel ve duygusal deneyimdir.

Tablo 1. Etnografik mülakat protokolü

\begin{tabular}{|c|c|}
\hline $\begin{array}{l}\text { En temel soru (mülakat sahibinin amacı, } \\
\text { kullanıciya direk olarak sorulmaz) }\end{array}$ & $\begin{array}{l}\text { Neden ve hangi marka zinciri tercih ediliyor veya } \\
\text { edilmiyor? Çekici ve itici gelen konular nelerdir? }\end{array}$ \\
\hline Protokol başlangicı & $\begin{array}{l}\text { Merhaba, adım kozmetik marka zincir mağazanın hangi } \\
\text { ihtiyacınızı gördüğünü anlamak için buradayım. Bu } \\
\text { mülakat yaklaşı 10-15 dakika sürecek. Mülakat } \\
\text { boyunca, duruma aşina olmayan birine anlatıyormuş } \\
\text { gibi davranmanı istiyorum. Senden öğrenmek için } \\
\text { geldim. Rızanız var mı? }\end{array}$ \\
\hline Isındirma Turu & $\begin{array}{l}\text { Araştırma sorusundan önce kısa sohbetlerle mülakatı } \\
\text { 1sındırıyoruz. Göz teması ve pozitif enerji verme çok } \\
\text { önemli. Hangi kozmetik zincir markasın } \\
\text { kullanmaktasınız? (sorunun devamı buna göre } \\
\text { şekillendirilir). }\end{array}$ \\
\hline [Mülakat başladıktan sonra...] & $\begin{array}{l}\text { Ses kaydı yapmamın sakıncası var mı? Bu sadece hiçbir } \\
\text { şeyi kaçırmamak için - benden başka hiç kimse } \\
\text { kayıtlara erişemez. Teşekkürler. }\end{array}$ \\
\hline $\begin{array}{l}\text { Son hikayeler (mülakat kuralları: açık, belli, } \\
\text { yönlendirici olmayan, duygulara, ilişkilere, } \\
\text { düşüncelere odaklı, iyi dinleyici) } \\
\text { Takip sorusu, cevabının içinde barındırmıyorsa }\end{array}$ & $\begin{array}{l}\text { Bana en son ne zaman A'dan bir ürün aldığını anlatır } \\
\text { mısın? } \\
\text { Hangisinden, neden bu ürünü aldın? Ne amaçla } \\
\text { kullanacaksın? } \\
\text { Eğer A'dan hiç ürün almadıysa neden almadın? }\end{array}$ \\
\hline A tercih & $\begin{array}{l}\text { Neden A'yı tercih ettin? } \\
\text { (Örneğin hesaplı olduğu için derse, takip sorularına } \\
\text { başlat. Neden hesaplı olduğunu düşünüyorsun gibi....) }\end{array}$ \\
\hline$A^{\prime} \mathrm{da}$ & $\begin{array}{l}\text { A'da yaşadığın bir memnuniyetsizlik oldu mu? (Yine } \\
\text { takip soruları) } \\
\text { Hangi duyguyla anlatırsın? Neden? }\end{array}$ \\
\hline A'da yaşamış olduğu bir memnuniyet & $\begin{array}{l}\text { A'da yaşadı̆̆ın bir memnuniyet oldu mu? (Yine takip } \\
\text { soruları) } \\
\text { Hangi duyguyla anlatırsın? Neden } \\
\text { Neden bir memnuniyet yaşamadın? }\end{array}$ \\
\hline A yerine & $\begin{array}{l}\text { A'dan almadığında nereden alıyorsun? } \\
\text { Neden orayı tercih ediyorsun? Yaşadığın olağanüstü bir } \\
\text { müşteri memnuniyeti oldu mu? Neden? }\end{array}$ \\
\hline Online hizmet & $\begin{array}{l}\text { A online alışveriş yaptın mı? Hangi ürün için? Anlatır } \\
\text { mısın? } \\
\text { Neden A online'dan alışveriş yapmadın? }\end{array}$ \\
\hline & Sormam gereken ama sormadığımı bir soru oldu mu? \\
\hline
\end{tabular}




\section{Bulgular}

\subsection{Kozmetik Ürün Temelinde: Kadınlar Bilinçli}

Etnografik çalışmalarda deneyimler üzerine soru sorulduğundan ne sıklıkta ziyaret edersiniz tarzında anket soruları sorulmamaktadır. Fakat, en canlı hafızasını canlandırmak için en son ne zaman uğradınız sorusuna karşın kadınlar ne sıklıkta gittiklerinden bahsetmeye başladılar: "Hafta 2 kez uğruyorum (K1). Hafta 1 kez uğruyorum (K4). Ayda 1 kez uğruyorum (K6). Karşıma çıtııça giriyorum (K2)".

Kadınlar kozmetik sektöründe çok bilinçli olduğu tespit edildi. Seri bir şekilde deneyimlerini aktardılar. Bu kadar sıklıkla ziyaret etmelerinden dolayı kullandıkları ürünleri ve mağazaları ayrıntılarıyla bilmekteler.

Tercihleri yerine oturmuştur: F...... kullanıyorum. Çünkü nerede üretildiğini (Türkiye'de) biliyorum. Kendileri üretiyorlar (K5). B.... O'nun yağglı rujunu alıyorum (K5). C'den alışveriş yapıyorum (K4). Gerekirse indirimi bekliyorum (K4).

Marka, ürün, mağaza algıları kuvvetlidir. Rastgele alışveriş yapmamaktalar. Sık sık kozmetik reyonlarını ziyaret etmekteler. Neredeyse, takım tutar gibi ürün ve marka tutmaktalar. Bu durum, reklam ve pazarlama sektörü açısından mevcut alışkanlıkları (mağaza, marka, ürün) kırmanın ve yeni bir ürünü, markayı tanıtmanın zorluğuna işaret etmektedir.

\subsection{Kullanıcı Deneyimleri}

Bulgular 5 kullanıcı deneyimi üzerinden kategorileştirildi: Fiziksel-bilişsel-sosyal-kültürel-duygusal (tablo 2). Kozmetik sektöründe kullanıcı iç görüleri arasında kültürel bir deneyimle karşılaşılmamıştır.

Araştırma sonrası katılımcıların ağırlıklı olarak tercih ettikleri markalar kategorileştirildiğinde, öylesine uğranılan (Türk menşeili -A-), aranan bulunulan (İngiliz menşeili -B-) ve heyecan veren (Fransız menşeili -C) marka deneyimi sunan olarak adlandırılmıştır. Markanın kimliğini açıkça gösteren ve akılda kalıcı isimlendirme kullanılır (Kumar, 2012).

Yerli marka duygusal bağ kuramamış, özensiz, fonksiyonel ihtiyaçları karşılayan üretecidir. Öylesine uğranılana göre aranan bulunan duygusal bağı kuramasa da kaliteli fonksiyonel malları satmakta ve çalışanları tüketicilerle ilgilidirler. Heyecan veren marka ise duygusal bağ kurmuş, kullanıcıların kendilerinin önemli hissettikleri bir yer olarak algilamaktalar.

Tablo 2. Markaların Kullanııı Deneyimine Göre Karşılaştırılması

\begin{tabular}{|c|c|c|c|}
\hline Kalite algısı & Öylesine uğranılan (A) & Aranan bulunulan (B) & Heyecan veren $(\mathrm{C})$ \\
\hline Duygusal & $\begin{array}{l}\text { Hoşuma gitmiyor } \\
\text { Menşeini bilmiyorum. }\end{array}$ & $\begin{array}{l}\text { Müşterisiyim. } \\
\text { Beğeniyorum. } \\
\text { İngiliz. } \\
\text { Her ikisi de (A \& B) benim } \\
\text { için eşit. Hangisi yolumun } \\
\text { üstündüyse O'nu tercih } \\
\text { ediyorum. }\end{array}$ & 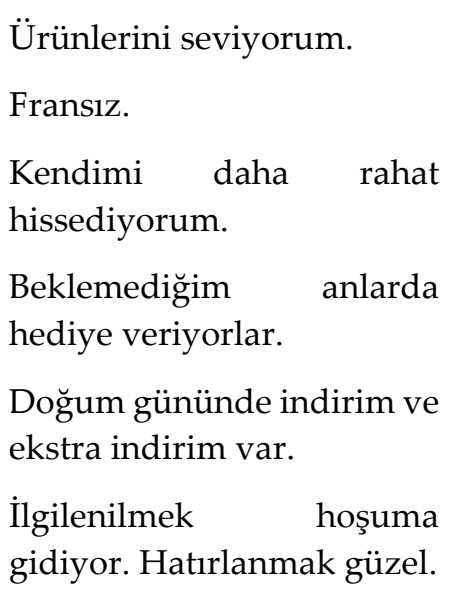 \\
\hline Bilişsel & $\begin{array}{l}\text { Toplama mal satar. } \\
\text { Mal kalitesi zayıf. } \\
\text { Ucuz ve kalitesiz }\end{array}$ & $\begin{array}{l}\text { Direk B'ye gidiyorum. A } \\
\text { aklıma gelmiyor. } \\
\text { Önce B'ye gidiyorum daha } \\
\text { çok beğeniyorum. }\end{array}$ & $\begin{array}{l}\text { Ürünleri daha kaliteli } \\
\text { geliyor. } \\
\text { Hep ödeme anında bir } \\
\text { hediye veya indirimi } \\
\text { oluyor. Aşağ yukarı 3-4 }\end{array}$ \\
\hline
\end{tabular}




\begin{tabular}{|c|c|c|c|}
\hline & $\begin{array}{l}\text { İstediğim markayı } \\
\text { bulamıyorum. } \\
\text { Paketlemeleri özensiz. } \\
\text { Estetik algısı zayıf. } \\
\text { Ambalaj, font hoş değil. } \\
\text { Ayda bir kez, kampanya } \\
\text { dönemlerinde gidiyorum. }\end{array}$ & $\begin{array}{l}\text { A yerine, B'yi tercih } \\
\text { ediyorum. } \\
\text { A BİM veya A101 ise B } \\
\text { Migros gibi. } \\
\text { A ve B orta, orta-alt kaliteli } \\
\text { makyaj malzemesi satıyor. } \\
\text { Yüksek kaliteli bir şey } \\
\text { bulamazsın. Sıradan şeyler } \\
\text { var. Migros'un bir } \\
\text { reyonunu alıp oraya } \\
\text { taşımışsın gibi aşağı yukarı. }\end{array}$ & $\begin{array}{l}\text { ayda bir alışveriş } \\
\text { yapıyorsan bir şey denk } \\
\text { geliyor. } \\
\text { Kampanya, indirim, hediye } \\
\text { derken ortalama fiyatları } \\
\text { makule geliyor. }\end{array}$ \\
\hline Sosyal & $\begin{array}{l}\text { Çabucak alırım ya da } \\
\text { bırakırım giderim. } \\
\text { Kozmetik ürünleri } \\
\text { pazarlanmadığında, } \\
\text { anlatamadığında } \\
\text { satabileceğin ürünler değil. } \\
\text { Çalışanlar memnuniyetsiz. } \\
\text { Ya uzun çalışıyorlar ya } \\
\text { işlerini sevmiyorlar. } \\
\text { Bilgilendirilme yapılmıyor. } \\
\text { Memnuniyetsiz çalışan } \\
\text { bilgide vermez. } \\
\text { Kasadaki davranışları } \\
\text { memnuniyetsizliklerine } \\
\text { yansıtıyor. } \\
\text { Elemanlar pek ilgilenmiyor. } \\
\text { Self-servis mantığı var. Bir } \\
\text { hizmet aldığımı } \\
\text { düşünmüyorum. Ancak } \\
\text { yapışacaksın. } \\
\text { Çok iç içe. } \\
\text { Organik var olabilir ama } \\
\text { standı yok. } \\
\text { Mimarisi hatalı. } \\
\text { Atmosfer itiyor. }\end{array}$ & $\begin{array}{l}\text { Ortamı daha çok hoşuma } \\
\text { gidiyor. } \\
\text { Daha ilgililer. } \\
\text { Personeli daha bilgili ve } \\
\text { güler yüzlü. İçiniz ısınıyor. } \\
\text { Daha sıcak, samimi. } \\
\text { Personeli } \\
\text { geçiyor. } \\
\text { Geniş. } \\
\text { Ferah. } \quad \text { User-friendly } \\
\text { kullanım alanı. }\end{array}$ & $\begin{array}{l}\text { Daha temiz, düzenli. } \\
\text { Danışmanlık alabileceğin } \\
\text { yer. Temasın yoğun olduğu } \\
\text { bir yer. Bilgi akıyor. }\end{array}$ \\
\hline Fiziksel & $\begin{array}{l}\text { Pamuk, aseton gibi çok } \\
\text { genel ürünleri alıyorum. } \\
\text { Çiğ mor renkler. Üstüne sarı } \\
\text { yazması. İç daraltıyor. } \\
\text { Marka renkleri hata. } \\
\text { Mağaza girişindeki yeşil } \\
\text { renk hoşuma gidiyor. Mor } \\
\text { hoşuma gitmiyor. }\end{array}$ & $\begin{array}{l}\text { Yeşil zemin ismini beyaz. } \\
\text { Daha çekici. } \\
\text { Marka, amblem olarak } \\
\text { tercih ederim. }\end{array}$ & \\
\hline
\end{tabular}




\section{3. Öylesine Uğranılan Bağlamında Temel Bulgular}

Hızlıca alışveriş yapılan ihtiyaç karşılanan ve çıkılan bir mağaza konumundadır. A kozmetik marka zincirine kadınlar öylesine girmektelerdir.

\section{Duygusal}

Kullanıcı deneyimi araştırması açısından en temel bulgu müşterisiyle duygusal bağ kurulamamasıdır. Müşterisinin ayrıcalıklı ihtiyaçlarını keşfedilememiş, sıradan temel malları kalitesi zayıf olarak satan bir marka konumunda olmasıdır. Markanın hikayesi belirsizdir: "Nadir giriyorum. Hoşuma gitmiyor (K2). Menşeini bilmiyorum. Araştırmak bile istemem (K1).

\section{Bilişsel}

Kullanıcılar kalitesiz, özensiz ve ucuz bulmaktalar: "Mal kalitesi zayıf (K19). Toplama mal satıyor (K3). A'da alma niyetiyle giriyorum. Ama her defasında almadan çıkıyorum (K2). El kremi aldım. Kendi markalı ürünü çok kötü çıktı. Yumuşak değil. Güzel kokmuyor (K1). Ucuz ve kalitesiz görüyorum (K13). Çünkü kendi sattığı mallar kalitesiz (K17). Makyajı, pamuğu,... Kalitesi daha düşük (K12). İstediğim markayı bulamıyorum (K16). Saç boyasında bakınıyorum (K4). Paketlemeleri özensiz (K8). Estetik algısı zayıf (K1). Ambalaj, font hoş değil (K17). Hâlbuki kozmetik ürünlerin de estetik ön plandadır (K1)".

Kadınlar kendi kullandıkları ürün ve mağaza markalarını söylerlerken, diğerleriyle karşılaştırmaktalar. “ $B$ ile A aynı kategoride. Ama A bir lig altında (K1)".

Bu karşılaştırmada öylesine uğranılan genelde olumsuz olarak değerlendirilmektedirler. Aranan bulunan (B) ile karşılaştırılmaktadırlar. Öylesine uğranılana talep daha düşüktür. Promosyon dönemlerinde, fonksiyonel ürünlerin satın alınmasında veya çok belirgin bir ürün için uğranılmaktadır. "Ayda bir kez, kampanya dönemlerinde gidiyorum (K2). Oreal'ın yağh rujunu alıyorum (K5)".

\section{Sosyal}

Mağaza ortamı iç açıcı değildir. Kullanıcılar kendilerini sıkışmış görmekteler: "Mimarisi hatalı (K1). Dükkân tasarımı kişilere karışık, düzensiz gelmektedir (K6). Çok iç içe (K2). Organik var olabilir ama standı yok (K1). Atmosfer itiyor. Almadan çıkıyorum. Kalbim ısınmıyor (K2). Sıkışık (K10)".

Müşterilerle ilişkileri çok zayıf olup müşterisiyle özel bir bağ kuramamaktadır: "Ya çabucak alırım ya da bırakırım giderim (K2). Çalışanlar memnuniyetsiz (K8). Ya uzun çalışıyorlar ya işlerini sevmiyorlar (K11). Bilgilendirilme yapılmıyor. Memnuniyetsiz çalışan bilgide vermez (K12). Kasadaki davranışları da memnuniyetsizliklerine yansıtıyor. Elemanlar pek ilgilenmiyor. Görevliler alakasız (K13). Hatta öyle ki kasaya gittiğimde ödeme yapabilir miyim diye birilerini çă̆ırıyorum. B'de de A'da da alacak mıyım almayacak mıyım diye ilgilenen kimse olmuyor içerde (K4). Olduğunu bildiğim bir ürünü sordum. Zor zahmet cevap verdi. Şuradan gidip, bilmem neresinde gibi eliyle cevap verdi. Burnuyla, kaşıyla, gözüyle işaret ediyor. Hâlbuki, küçük dükkan "size yardımcı olayım, beraber gidelim" demesi gerekliydi (K3)".

Self-servis tarzında çalışmaktadır. Hâlbuki tüketim ürünleri ve özellikle kozmetik pazarlanması ve müşteriyle yakın temas kurulması gereken ürünlerdir: "Kozmetik ürünleri pazarlanmadığında, anlatamadığında satabileceğgin ürünler değil (K1). Self-servis mantı̆̆ı var. Bir hizmet aldığımı düşünmüyorum (K11). Ancak yapışacaksın (K8)".

\section{Fiziksel}

Duygusal bağ kurulamamasının neticesi olarak fonksiyonel ihtiyaçları karşılama konumundadır. Kullanıcının aklında olmayan bir tercih olarak karşısına çıktığında, hiçbir şey bulamadım bir de "buraya uğrayım" düşüncesi taşımaktadır. Sadece fonksiyonel ihtiyaçları karşılamaktadır: "Pamuk, aseton gibi çok genel ürünleri alıyorum (K3). Çiğ mor renkler. Üstüne sarı yazması. İç daraltıyor (K2). Marka renkleri hata (K8). Dükkân girişindeki yeşil renk hoşuma gidiyor. Mor hoşuma gitmiyor (K2).

\subsection{Aranan Bulunan Bağlamında Temel Bulgular}

Aranan bulunanda temel kozmetik ihtiyaç ürünleri kaliteli olarak bulunmaktadır. Güvenli alışveriş yapılan bir merkezdir.

\section{Duygusal}


Aranan bulunanda (B) markasının duygusal deneyimi öylesine uğranılan markasına göre biraz daha iyi ama genelde zayıftır. Ağırlıklı olarak kaliteli fonksiyonel ürün satan olarak algılanmaktadır. Özel olarak tercih edilmemektedir: B müşterisiyim. B'yi seviyorum (K2). A ile B benim için eşit. Hangisi yolumun üstündüyse $O^{\prime} n u$ tercih ediyorum (K3). B'de miydim, A'da mıydım. Kasaya gittim. Aldığım ürünleri bıraktım. Yavaş ve ilgisizler (K4).

\section{Bilişsel}

Temel ürünleri kaliteli üretir algısı mevcuttur. B her kategoride başarılı bulunmuyor. Ama bütünsel olarak algıda A'ya göre daha kuvvetlidir.

A ve B orta, orta-alt kaliteli makyaj malzemesi satıyor. Yüksek kaliteli bir şey bulamazsın. Stradan şeyler var. Migros'un bir reyonunu alıp oraya taşımışsın gibi aşă̆ı yukarı (K7). El kremi aldım. Yumuşaklığı ve kokusu iyi (K1). Direk B'ye gidiyorum. A aklıma gelmiyor (K9). Önce B'ye gidiyorum daha çok beğeniyorum (K2). A yerine, B'yi tercih ediyorum (K14). A BìM veya A101 ise B Migros gibi (K1). B'yi (A'ya göre) daha kaliteli buluyorum (K15).

\section{Sosyal}

Aranan bulunanda personel ilgisi yüksek, bilgisi kuvvetli, tavrı olumludur. Personeline özel eğitim verildiği düşünülmektedir. Mağaza tasarımında geniş, ferah algısı vardır: Ortamı daha çok hoşuma gidiyor (K11). Daha ilgililer (K9). Personeli daha bilgili ve güler yüzlü. İçiniz ısınıyor. Daha sıcak, samimi (K2). Personeli eğitimden geçiyor. Bilgiler daha iyi (K2). Görevliler alakasız. Hatta öyle ki kasaya gittiğimde ödeme yapabilir miyim diye birilerini çağırıyorum. B'de de A'da da alacak mıyım almayacak mıyım diye ilgilenen kimse olmuyor içerde (K14). Daha ferah. User-friendly kullanım alanı (K7). Geniş (K9).

\section{Fiziksel}

Markanın rengi, amblemi beğenilmektedir: Marka, amblem olarak B'yi A'ya göre tercih ederim (K7). Yeşil zemin ismini beyaz. Daha çekici (K9). Boş kutu, şişe var. Büyük şişeleri taşımak istemediğinizde küçüklere koyuyorsunuz (K2).

\subsection{Heyecan Veren Bağlamında Temel Bulgular}

Heyecan veren markada ise "İlgilenilmek hoşuma gidiyor. Hatırlanmak güzel" denilerek kullanıcıların geçirdikleri kuvvetli duygusal deneyimi işaret etmektedir. Önemsenmek, özen gösterilmek, rahat hissetmek markayla iletişimde önemli duygulardır. Markanın aralıklarla kullanıcılarına sürprizler vermesi kadınları heyecanlandırmaktadır. Ürün ve hizmet kalitesi mükemmeldir.

\section{Duygusal}

Heyecan veren markanın duygusal deneyimi olağanüstüdür. Tüketiciler ürünleri sevmekteler, kendilerini rahat hissetmekteler, hoş sürprizlerle karşılaşmaktalar, özel günlerde hatırlanmaktalar. Kendilerini iltifata tabi tutulmuş kadın gibi hissetmekteler. Ürünlerini seviyorum (K14). Kendimi daha rahat hissediyorum (K11). Beklemediğim anlarda hediye veriyorlar. Bir alışveriş esnasında duş jeli alıyordum. Kasaya gittim. Ödeme yapacağım. Görevli dedi ki duş jeli hediyeniz var. Bunun üzerine bir tane şampuan aldım. İki büyük boy duş jeli ücretsiz aldım (K4). Doğum gününde indirim ve ekstra indirim var (K11). Ilgilenilmek hoşuma gidiyor. Hatırlanmak güzel (K13).

\section{Bilişsel}

Fiyatları bir nebze yüksekse de, kalite performansı, promosyonlar takibi, hediye ürünler ve çok miktarda alımı ortalama fiyatları oldukça indirmektedir. Ürünleri daha kaliteli geliyor (K14). İlgileniyorlar. Kampanya, indirim, hediye derken ortalama fiyatları makule geliyor. Fiyat olarak optimumda. .... shoplar daha önce vardı. Ama bununla ayn randımanda değil (K9). Hep ödeme anında bir hediye veya indirimi oluyor. Aşağı yukarı 3-4 ayda bir alışveriş̧ yapıyorsan bir şey denk geliyor (K4).

\section{Sosyal}

Mağaza içi rahatça alışveriş yapacak şekilde tasarlanmış. Personelin ilgisi özenli ve bilgilendirmesi tatminkârdır. Ayrıca satıcıları aynı zamanda danışman gibi görülmektedir: Temiz, düzenli (K5). Ferah (K6). C'de danışmanlık alabileceğin. Temasin yoğun olduğu bir yer. Bilgi akıyor (K3) 


\subsection{Alternatifler, Online, Erkekler}

\section{Kozmetik Zincir Mağazaların Alternatifi: Migros Ve Kozmetik Mağazalar}

Kozmetik zincirlerden alışveriş yapmadıklarında nereden aldıkları sorulduğunda tüketiciler ağırlıklı olarak Migros'u işaret etmekteler. Migros perakende devi olarak önemli bir konuma sahiptir. Kullanıcıların iç görülerine dayanarak bir tane ana avantajı vardır: Kolaylık. Kadın müşteriler Migros'a herhangi bir ihtiyaçlarını almak için gittiklerinde kozmetik ürünlerini de almaktalar. Kozmetik mağazalarının Migros'a göre avantajları ise fiyat, çeşit ve uzmanlaşmadır. Katılımcılar açısından ürünler genel ve ayrıcalıklı olarak ikiye ayrılmışlardır. Migros genel ürünlerin alındığı yer olarak görülmektedir. Zincir mağazalar arasında öylesine uğrananda genel ürünlerin alınabileceği alternatif bir mekân olarak algılanmaktadır. Ayrıcalıklı marka kategorisinde değildir: "Alışverişimi yaparken kozmetiği de Migros'tan alıyorum (K3). Migros gittiğimde şampuan gibi kozmetik ürünlerini Migros'tan alıyorum. Ayricalıkl ürünleri C'de (heyecan uyandıran) (K4). Migros'ta haftalık alışverişimi yaparken kulak çubuğu, pamukta aldım. A (öylesine uğranan) evime yakın ama hazır oradayken hallediverdim (K8). Migros yerine tercih ediyorum. Diğer kozmetik dükkanları daha ucuz (K11). Daha fazla indirim var. Kozmetik dükkanları uzmanlaşmışlar (K3). Kozmetik dükkanlarında ürün çeşitliliği var (K16). Migros'ta kısıtlı ürün var (K7). O alanda uzmanlaşmış ürünü tercih ediyorum (K9). Çok indirim var (K4)".

\section{Online Kullanma}

Kozmetikte online kullanım özel ürünlerde ve lokasyon olarak uzakta olduğunda tercih edilmektedir: "Bu ürün grubunda online kullanmıyorum. Her yerde buluyorum (K10). Sadece ayrıcalıkl ürünlerde (A ve B'de yok), online alıyorum. Özellikli ve nitelikli. Mesela Dermo Eczane Mustela markasının ürünleri var. A'da en iyi marka L'oreal'i bulurken, orada Rocher, Vichy'ler şunlar bunlar, daha nitelikli markalar var (K1)".

\section{Erkekler}

Kozmetik zincir markalarla ilgili erkeklere sorulduğunda genellikle bilmedikleri veya dikkat etmedikleri sonucu çıkarıldı. Ne sattıklarını bilmiyorum (E1). Ne olduklarını bilmiyorum (E2). Market olduklarını biliyorum (E3). Galiba kozmetik ürün satıyorlar (E4). Birkaç defa eşimi beklerken görmüştüm (E5). Bir defa su almak için girmiştim (E6). Eşim sipariş verdiğinde almıştım (E7). Ancak burada erkeklere yönelik birtakım fırsatlar olabileceği göz ardı edilmemelidir.

\section{Sonuç ve Tartışma}

Bu çalışmada kadınların sıklıkla kozmetik zincirlerine gittikleri, sektör, ürünler ve mağazalar hakkında derin bilgiye sahip oldukları ortaya konmuştur. Çarşıya veya dışarıya çıkıldığında uğranılan bir mekân haline dönüşmüştür. Literatürle uyumlu olarak online ticaretin gelişmesine rağmen kadın tüketicinin mağazadan almayı tercih ettikleri anlaşılmıştır (Yang ve Lee, 2016). Elde edilen çıkarımların sonucunda mağazanın tasarımından müşteri ilişkilerine kadar tüm unsurların satışı etkileyebileceğini göstermektedir.

Kullanıcı deneyimi olarak hikayeler 5 deneyimde kategorileştirildi: duygusal, bilişsel, sosyal, kültürel ve fiziksel. Aralarındaki en önemli deneyim kullanıcıyla marka arasında kuvvetli bağ kurulmasını sağlayan duygusal olandır. Markanın hikayesi de bu duygusal deneyim üzerinden inşa edilmelidir.

Kozmetik sektöründe, kadınlar kendi kullandıkları ürün ve mağaza markalarını bahsederlerken, diğerleriyle karşılaştırmaktalar. Kadınların kullandıkları zincir mağazalar arasında sıklıkla ziyaret ettikleri üç marka kavramı öğrenilmiştir: Öylesine uğranan, aranan bulunan ve heyecan veren. Bu karşılaştırmada öylesine uğranılan genelde olumsuz olarak değerlendirilmektedir. Mülakatlar esnasında tercihte rol oynayan sebepler derinlemesine inildi.

"Öylesine uğranılanda" düşük kalitede kalma sebepleri gruplandığında: ürün kalitesi, insan kaynakları, mağaza tasarımı, renkler ve paketleme ön plana çıkmaktadır. Kalite algısında "aranan bulunan" olmak üzere "heyecan verenin" kendi ürettikleri daha çok tercih edilmektedir.

Öylesine uğranılanının en zayıf olduğu nokta insan kaynağıdır. Müşteri memnuniyeti çok düşüktür. Ne kadar iyi üründe olsa, bir halka zayıfsa kullanıcı gözünde kalitesi düşmektedir. Çalışanların sundukları hizmetlerin 


\section{M. Ş. Akın 13/1 (2021) 13-28}

kalitesi beğenilmemektedir. Renk seçimi konusunda eleştiriler vardır. İç açıcı bulunmamaktadır. Diğer markaların menşei bilinirken bu markanınki bilinmiyor.

Aranan bulunanda tüketicinin aradığını bulduğu kendisini ürün ve hizmet kalitesi açısından konforlu hissettiği bir mekandır.

Heyecan verenin markasının aralıklarla kullanıılarına sürprizler vermesi kadınları heyecanlandırmaktadır. Kadınlar markayı kendisine yakın hissetmesidir. Önemsenmek, özen gösterilmek, rahat hissetmek markayla iletişimde önemli duygulardır. Ürün ve hizmet kalitesi mükemmeldir. Çalışanlar danışman konumundadırlar. Kampanyaları ve indirimleri takip edilmektedir. Bu kategoride de özellikle tercih edilen bir marka olarak ön plana çıkmaktadır.

Öylesine uğranan markanın bir değişimden geçmesi gereklidir. Özellikle kullanıcıyla duygusal bağın kurulması kuvvetlendirilmelidir (Pine ve Gilmore, 2011). Duygusal bağın kurulması, tercihte ön sırayı getirecektir. Ancak bu dişsal motivasyonla değil içsel motivasyonla gerçekleşebilir (Pink, 2011). Burada şirketle beraber ortak kurgulama mekanizmasıyla bir yol haritası çıkartılmalıdır (Luma, 2014). Değişim küçük adımlarla gerçekleştirilir (Kelley and Kelley, 2013).

Aranan bulunan markanın ürünleri, mağazanın tasarımı, müşterilerle ilişkileri kalitelidir. Müşteri soru sorduğunda mağaza çalışanları ilgililerdir. Markadaki eksik unsur bütünlüktür. Sadece mağazaya giren müşterinin sorusuna cevap vermek, kullanıcının derinden gelen ihtiyacını cevaplamamaktadır. Heyecan veren markada kadın kendisinin önemsendiği, özen gösterildiği, ilgilenildiğini hissetmektedir. Bu duyguyu geçirecek şekilde insan kaynakları, mağaza tasarımı ve ürün kategorisi oluşturulmalıdır.

Heyecan veren marka kalite/fiyat performansında çok başarılıdır. Kullanıcı aldığı hizmeti, ürün kalitesi ve promosyonları göz önüne aldığında fiyatın yüksekliğinden şikâyet etmemektedir. Promosyonların doğru kurgulanması önemlidir. Özellikle müşterinin özel günlerinde seçici davranılması promosyona anlam katacaktır. Sürekli gelen müşterinin ödüllendirilmesi doğru stratejidir. Kadın müşterilerde kendilerini önemsendiklerini hissettirilmeleri çok önemlidir. Alışveriş yapmaya zorlamadan hatta teşvik dahi etmeden bu özenin çok açık şekilde hissettirilmesi gereklidir. Müşterinin motivasyonu güzelleşmek ve kendisini güzel hissetmektir. Marka müşteri iletişimi bu kavram üzerinden kurgulanmalıdır.

$\mathrm{Bu}$ çalışmanın sonucunda Türk menşeili firmanın zincir mağazalar arasında zayıf olduğu görülmektedir. Türk firmalarının gelecek dönemde ürün ve müşteri ilişkisinin geliştirmelerinin yanında kullanıı deneyimlere de odaklanmaları gerektiğini göstermektedir.

Bundan sonra yapılması gereken ve makale konusu olabilecek çalışmalar aşağıda sıralanmıştır:

İnsan kaynakları konusunda şirketin ek bütçe yükü getirmeden insan kaynağının iyileştirilmesidir. Şirket içinde ve dışında çalışanlar, insan kaynakları uzmanları ve eğitmenlerle mülakat yapılmalıdır.

Zincir markalar kendi marka ürünleri satmaktadır. Ürün kalitesinde kullanıcıların yaşadıkları kaygıların ortaya çıkartılması gereklidir.

Mağaza tasarımı, renk, paketleme konusunda kullanıcıların beklentilerinin ortaya konması ve çalışanlar, tasarımclar ve kullanıcılar ile ortak kurgulama (co-creation) mekanizmasıyla ilerlenmelidir (Liedtka vd., 2014; Borwn, 2009). Etnografi sadece şirkete bilgi aktarmakla yetinmemekte aynı zamanda çözümde de nasıl ortaklaşa harekete geçirildiğini göstermektedir.

Kadınların makyaj yapma sebeplerini, beklentilerini anlamaya yönelik daha derinlemesine etnografik araştırmaların yapılmalıdır. Gerek inovasyonda gerekse de pazarlamada kullanılabilecek birçok kavramın ortaya çıkarılmasına destek olacaktır (Zaltman ve Zaltman 2008).

Erkeklerin kozmetik zincir mağazalarda ilgisizliği bir çıkarım dahi olsa da hediye alma gibi konularda yönlendirici fırsatlar gözden kaçırılmamalıdır.

Kadınların kozmetik sektörü dışında da hesaplı ama kaliteli hizmet aldıkları yerlerdeki özelliklerinin belirlenmesi gereklidir. Burada elden edilen çıkarımlar kozmetik sektörüne aktarılabilir. 


\section{Kaynakça}

Akın, M S. (2019a). Kullanıcı Gerçekten Ne İster? Etnografik Metotları İle Derinlemesine Araştırma, Anadolu İktisat ve İşletme Dergisi, 3 (1), 1-25

Akın, M. S. (2019b). Kullanıcının bağlamının önemi ve bağlamsal sorgulama, Istanbul Management Journal, 87, $1-25$.

Akın, M. S. (2020). Advanced Design Thinking Model For Innovation and Entrepreneurship: Ethnographic, Brainstorming, Prototyping (EBP Canvas Method), Berlin, Lambert Publishing.

Aykaç, S.Ö. \& Kervenoael, R.D. (2008). Türkiye'de e-Bankacllk: Tüketici Deneyimleri, 13. Kapadokya: Ulusal Pazarlama Kongresi.

Babaoğul, M. \& Altyok, N. (2010). Türkiye'de ve AB Ülkelerinde Tüketici Eğitimi, Tüketici Araştırma Test ve Eğitim Merkezi, Ankara, Hacettepe Üniversitesi,

Babaoğul, M. \& Bener, Ö. (2010). Yeni Teknolojiler ve Tüketici Etkileşimi. Tüketici Yazıları II, Ed. Müberra Babaoğul ve Arzu Şener, ss. 103-116. Ankara:TUPADEM

Beckman, S. L. \& Barry, C. M. (2007). Innovation as a Learning Process: Embedding Design Thinking, California Management Review, 50 (1), 25-49

Blasberg J, Vishwanath V \& James A. (2007). Turning your consumers into die-hard fans

https://www.bain.com/insights/turning-your-consumers-into-die-hard-fans/

Brown, T. (2008). Design Thinking, Harvard Business Review, 5(3), 56-65

Brown T. (2009). Change by Design: How Design Thinking Transforms Organizations and Inspires Innovation. New York: Harper Business.

Canniford, R., (2005). Moving Shadows: Suggestions for Ethnography in Globalised Cultures, Quantitative market Research, 8(2), 204- 218.

Christensen C. M., Hall, T., Dillon K., and Duncan D. S. (2016), Know Your Customers' “Jobs to Be Done.” Harvard Business Review, September.

Cliquet, G. \& Croizean, J. (2002). Towards plural forms, franchising/company-owned systems, in the French cosmetics retail industry. International Journal of Retail \& Distribution Management, 30, 5, 238-250.

Coulter, R. A., Zaltman, G., \& Coulter,K. S. (2001). Interpreting Consumer Perceptions of Advertising: An Application of the Zaltman Metaphor Elicitation Technique, Journal of Advertising, 23 (3): 45-57.

Court, D., Elzinga, D., Mulder, S. \& Vetvik, O.J. (2009). The consumer decision journey. McKinsey Quarterly, 3, 96-107

Coşgun, M. (2012). Popüler Kültür ve Tüketim Toplumu. Batman Üniversitesi Üniversitesi Yaşam Bilimleri Dergisi, 1(1), 837-850.

Creswell J. W. \& Creswell J. D. (2017). Research Design: Qualitative, Quantitative, and Mixed Methods Approaches 5th Edition. New York, SAGE Publications, Inc.

Devranï, T.K. (2009). Marka Sadakati Öncülleri: Çalışan Kadınların Kozmetik Ürün Tüketimi Üzerine Bir Çalışma, Süleyman Demirel Üniversitesi İktisadi ve İdari Bilimler Fakültesi Dergisi, 14 (3) , 407-421 .

Elliot, R. \& Elliot N.J. (2003). Using Ethnography in Strategic Consumer Research, Qualitative Market Research An International Journal, 6(4), 215-223.

Faulkner, L. (2003). Beyond the five-user assumption: Benefits of increased sample sizes in usability testing. Behavior Research Methods, Instruments, \& Computers, 35, 379-383.

Gourville, J. T. (2006). Eager Sellers and Stony Buyers: Understanding the Psychology of New-Product Adoption. Harvard Business Review, June. 
M. Ş. Akın 13/1 (2021) 13-28

Hall, T., \& Wengel, R. (2016), “Nielsen Breakthrough Innovation Report from 2012-2016. https://www.nielsen.com/wp-content/uploads/sites/3/2019/04/nielsen-us-breakthrough-innovation-report2015.pdf

İmam F. (2013), Gender Difference in İmpulsive Buying Behavior and Post Purchasing Dissonance :Under İncentive Consitions, Journal of Business Strategies, 7, 1

İnceoğlu M., (2010). Tutum Algı İletişim, İstanbul, Beykent Üniversitesi Yayınevi.

İslamoğlu, H. \& Altunışık, R., (2008). Tüketici Davranışları. İstanbul, Beta

Odabaşı Y. \& Barış G., (2010). Tüketici Davranışı, İstanbul, MediaCat Yayınları.

Janakiraman, Narayan; Meyer, Robert J.; Morales, Andrea C. (2006-12-01). "Spillover Effects: How Consumers Respond to Unexpected Changes in Price and Quality". Journal of Consumer Research. 33 (3): 361369.

Kabadayı, E. T. \& Alan, A. K. (2014). Deneyimsel Pazarlama: Pazarlamadaki Artan Önemi, İşletme Araştırmaları Dergisi, 6 (1), 203-217.

Kahle, L.R.\& Kim, C.H. (2006). Creating Images and Psychology of Marketing Communication, New Jersey, Lawrence Erlbaum Associates, Inc., Publishers.

Kahn, B. E. (2013). Global Brand Power: Leveraging Branding for Long-Term Growth (2013) Wharton School Press.

Kelley, T., \& Kelley, D. (2013). Creative Confidence: Unleashing the Creative Potential Within Us All, New York, Crown Business.

Kumar, V. (2012). 101 Design Methods: A Structured Approach for Driving Innovation in Your Organization, Chicago, Wiley.

Lee, K. J. (2010). Current situation and future prospective of cosmetics industry in Taiwan. Chemical Industry, $5,57$.

Lembet, Z. (2010). Lüks Tüketim ve Lüks Markalar, Ankara:, Hacettepe Üniversitesi Tüketici Araştırma Test ve Eğitim Merkezi, II. Basım.

Liedtka J. \& Ogilvie, T. (2011). Designing for Growth. New York, Columbia Business School,

Liedtka, J., King, A. \& Bennett, K. (2014). Solving Problems With Design Thinking, New York, Columbia Business School.

Łopaciuk, A. \& Łoboda, M. (2013). Global beauty industry trends in the 21st century. Management, knowledge and Learning. 1079-1087.

Luma Insistutue. (2012). Human Centered Design. Pittsburg, Free Press,.

Luma Institute. (2014). Innovation of Taxanomy. Harvard Business Review, Jan/Feb issue.

Manning, H. \& Bodine, K. (2012). The 6 Disciplines Behind Consistently Great Customer Experiences. Fast Company.

Marangoz M., (2007), Marka Değeri Algılamalarının Marka Yayılmaya Etkileri. Ege University Faculty of Economics and Administrative Sciences, 7, 2

Merriam S.B. \& Tisdell E. J. (2015). Qualitative Research: A Guide to Design and Implementation. John Wiley \& Son.

Meyer, A. (2006). Are you experiential? Multi-channel Merchant, 12(8): 1-55.

Meyer C, \& Schwager A (2007). "Understanding Customer Experience". Harvard Business Review. 85 (2): 112.

Moisander, J. \& Voltanen, A. (2011). Interpretive Marketing Research: Using Ethnography In Strategic Market Development. in Lisa Penaloza; Nil Toulouse and Luca M. Viscontı (Eds.), Marketing Management: A Cultural Perspective, First Edition, London: Routledge. 


\section{M. Ş. Akın 13/1 (2021) 13-28}

Nardalı, S. \& Balkan, E . (2019). Sosyal Medya Fenomenleri: Instagram Ve Kozmetik Sektöründe Bir Uygulama, İzmir Katip Çelebi Üniversitesi İktisadi ve İdari Bilimler Fakültesi Dergisi, 2, 2, 176-187.

Nielsen, J. (2000). Why You Only Need to Test with 5 Users. https://www.nngroup.com/articles/why-youonly-need-to-test-with-5-users/

Nielsen, J. (2020). How Many Test Users in a Usability Study? https://www.nngroup.com/articles/how-manytest-users/

Oğuz, G . (2013). Güzellik Kadınlar İçin Nasıl Vaade Dönüşür: Kadın Dergilerindeki Kozmetik Reklamları Üzerine Bir İnceleme, Selçuk İletişim, 6, 3, 184-195.

Özden, E \& Özden, Z . (2020). İkinci Dalga Feminizmin Kozmetik Reklamlarının Görsel-Metinsel Tasarımı Üzerindeki Etkisi, Selçuk İletişim, 13, 1, 1-23.

Piaget, J., \& Inhelder, B. (1969). The Psychology Of The Child. New York: Basic Books.

Pine, J., \& Gilmore, J. (2011). The Experience Economy, Cambridge, Harvard Business Review Press.

Pink, D. (2011). Drive: The Surprising Truth About What Motivates Us. New York: Riverhead Books.

Schmitt, B. H. (1999). Experiential Marketing, How to Get Customers to Sense, Feel, Think, Act, Relate, New York, The Free Press.

Schmitt, B., \& Zarantonello, L. (2013). Consumer experience and experiential marketing: a critical review, Review of Marketing Research, 10, 25-61.

Sebor, J. (2008). CRM Gets Serious. CRM Magazine.

Souiden, N. \& Diagne M. (2009). Canadian and French men's consumption of cosmetics: a comparison of their attitudes and motivations. Journal of Consumer Marketing, 26, 2.

Standford Design School (2009), d.school bootcamp bootleg. www.dschool.standford.edu http://www.youtube.com/watch?v=-FzFk3E5nxM (Erişim tarihi20.03.2019).

Srinivasan, S. R. \& Srivastava, R. K. (2010). Creating the futuristic retail experience through experiential marketing: Is it possible? An exploratory study. Journal of Retail \& Leisure Property, 9, 193-199

Varinli, İ. (2006). Pazarlamada Yeni Yaklaşımlar, Ankara, Detay Yayıncılık.

Zaltman, G. \& Zaltman,L. (2008). Marketing Metaphoria: What Deep Metaphors Reveal about the Minds of Consumers. Boston, Harvard Business School Press.

Zaltman, G. \& Zaltman, L. (2006). What Do 'Really Good' Managers and 'Really Good' Researchers' Want of One Another?, The Handbook of Marketing Research: Uses, Misuses, and Future Advances, 37 (2): 33-48.

Zaltman, G. (2003). How Customers Think: Essential Insights into the Mind of the Markets, Boston, Harvard Business School Press.

Yang, Dong-Jenn; Lee, C. W. (2016). In-store promotional mix and the effects on female consumer buying decisions in relation to cosmetic products, International Journal of Management, Economics and Social Sciences, 5, 2, 35-56.

Young, I. (2015). Practical Empathy: For Collaboration and Creativity in Your Work, New York: Rosenfeld Media. 